\title{
Paleoproterozoic source contributions to the São Roque Group sedimentation: LA-MC-ICPMS U-Pb dating and Sm-Nd systematics of clasts from metaconglomerates of the Boturuna Formation
}

Contribuições de fontes Paleoproterozoicas para a sedimentação do Grupo São Roque: datação U-Pb LA-MC-ICPMS e sistemática Sm-Nd dos clastos dos metaconglomerados da Formação Boturuna

\author{
Renato Henrique-Pinto ${ }^{1}$, Valdecir de Assis Janasi ${ }^{1}$, Antonio Simonetti ${ }^{2}$, Colombo Celso Gaeta Tassinari ${ }^{1}$, \\ Larry Michael Heaman ${ }^{3}$ \\ ${ }^{1}$ Departamento de Mineralogia e Geotectônica, Instituto de Geociências, Universidade de São Paulo - USP, Rua do Lago 562, \\ CEP 05508-080, São Paulo, SP, BR (renatohp@usp.br; vajanasi@usp.br; ccgtassi@usp.br) \\ 2Department of Civil Engineering and Geological Sciences, University of Notre Dame, South Bend, US (antonio.simonetti.3@ \\ nd.edu) \\ ${ }^{3}$ Department of Earth \& Atmospheric Sciences, University of Alberta, Edmonton, CA (larry.heaman@ualberta.ca)
}

Received 14 March 2012; accepted 26 July 2012

\begin{abstract}
The São Roque Group is characterized by volcano-sedimentary sequences, in which deposition probably started in the late Paleoproterozoic. U-Pb dating by LA-MC-ICPMS of zircons extracted from predominantly equigranular monzogranites clasts from Morro Doce and Morro do Polvilho regions, yield paleoproterozoic ages of $2199 \pm 8.5 \mathrm{Ma}$ and $2247 \pm 13 \mathrm{Ma}$, respectively. These represent the ages for the main source of granite for the metaconglomerates from the Boturuna Formation (basal unit of São Roque Group). Its polycyclic history is reinforced by the presence of inherited Archean zircons $(2694 \pm 29 \mathrm{Ma})$ found within the clasts. Moreover, these clasts have also been affected by the Neoproterozoic overprinting event as indicated by their lower intercept Concordia ages. Sm-Nd isotope data for the main clast varieties from the Morro Doce metaconglomerates yield $\mathrm{T}_{\mathrm{DM}}$ ages of 2.6 to $2.7 \mathrm{Ga}$, demonstrating that these granites are the recycling products of an Archean crustal component. The metaconglomerate arkosean framework yields slightly lower $\varepsilon_{\mathrm{Nd}(t)}$ values than those for the clasts, indicating that a younger and/or more primitive source also contributed to the Boturuna Formation.
\end{abstract}

Keywords: São Roque Group; Metaconglomerates; U-Pb dating; Sm-Nd data; Provenance.

\begin{abstract}
Resumo
O Grupo São Roque é caracterizado por uma sequência vulcanossedimentar com deposição provavelmente iniciada no Paleoproterozoico tardio. Datações U-Pb obtidas por LA-MC-ICPMS de zircões extraídos das variedades predominantes dos clastos de monzogranitos equigranulares, das regiões do Morro Doce e Morro do Polvilho, mostram idades paleoproterozoicas de $2199 \pm 8,5 \mathrm{Ma}$ e $2247 \pm 13 \mathrm{Ma}$, respectivamente. Estas representam as idades da principal fonte de granito da Formação Boturuna (unidade basal do Grupo São Roque). A história policíclica deste domínio é reforçada pela presença de zircões arqueanos herdados $(2694 \pm 29 \mathrm{Ma})$, encontrados nos clastos. Além disso, tais clastos também foram afetados pelo evento Neoproterozoico, conforme indicado pelo intercepto inferior das idades concórdia. Dados isotópicos Sm-Nd para os principais clastos do metaconglomerado do Morro Doce têm idades $\mathrm{T}_{\mathrm{DM}}$ entre 2,6 a 2,7 Ga, demonstrando que estes granitos são produtos da reciclagem de um componente crustal arqueano. $\mathrm{O}$ arcabouço dos metaconglomerados, quando comparado com os clastos, mostra valores mais baixos de $\varepsilon_{\mathrm{Nd}(\mathrm{t})}$, indicando contribuições de fontes mais jovens e/ou primitivas para a Formação Boturuna.
\end{abstract}

Palavras-chave: Grupo São Roque; Metaconglomerados; Datação U-Pb; Dados Sm-Nd; Proveniência. 


\section{INTRODUCTION}

The depositional age and geological significance of the São Roque Group (SRG) (Mantiqueira Tectonic Province, in Southeast Brazil) remain the focus of considerable debate in the geological literature. Several meta volcano-sedimentary sequences have been recognized in the so-called São Roque Domain. This includes the Serra do Itaberaba Group, which has been recognized as a medium-grade metamorphic sequence with a depositional age of $\sim 1.5 \mathrm{Ga}$ (Juliani et al., 2000), and is distinct relative to the lowergrade sequences that are commonly grouped into the SRG. The SRG itself is considered by some authors (Juliani, 1993; Martin, 2000) as a younger sequence, in view of its lower-grade metamorphism and proposed erosional contact marked by the presence, in metaconglomerates from its basal sequence (Boturuna Formation), of clasts and volcanic fragments, which are correlated to the Serra do Itaberaba Group (SIG). However, U-Pb zircon dating of acid and basic metavolcanic rocks from the Boturuna Formation has yielded consistently older ages $(1790 \pm 14$ Ma; van Schmus et al., 1986; $1750 \pm 40 \mathrm{Ma}$; Oliveira et al., 2008), strongly suggesting that SRG in fact corresponds, at least in part, to an older sequence (Henrique-Pinto and Janasi, 2010).

The metaconglomerates study from the SRG basal sequence has a long history, with the pioneering study by Derby (1882), who first documented the occurrence of such rocks in Brazil. A subsequent study by Coutinho (1955) reported a detailed description of the metaconglomerates, which are characterized by pebbles and boulders largely granitic in nature within an arkosean framework. These occur as meter to hectometre-sized lenses within a dominantly psammitic sequence. The intercalated bimodal suite of metavolcanic rocks that was used to determine the age of deposition occurs as thin layers and is characterized by a within-plate geochemical signature (Henrique-Pinto, 2008).

We have reported here the results of LA-MC-ICPMS $\mathrm{U}-\mathrm{Pb}$ zircon dating of granitic clasts and $\mathrm{Sm}-\mathrm{Nd}$ isotope determinations for granitic and amphibolite clasts, and for the framework of the metaconglomerates. Together with the previously reported geochemical data, these new results are used to aid in elucidating the provenance of the SRG and therefore contribute for understanding its tectonic significance.

\section{TECTONIC SETTING}

The São Roque Domain is a tectonic block that is located between the high-metamorphic grade Socorro-Guaxupé Nappe to the north (currently interpreted as related to the evolution of the southern branch of the Brasília Fold Belt), and the Embu Domain to the south (related to the Ribeira Fold Belt), as observed in Figure 1. In the tectonic model of Campos Neto (2000), the São Roque Domain is part of a larger block dominated by meta-volcano-sedimentary sequences metamorphosed to low-to-medium-grade conditions (the Apiaí-São Roque Domain). When together with the Socorro-Guaxupé Nappe, these correspond to a magmatic arc domain developed at the border of an older cratonic nucleus, which is mostly concealed beneath the Phanerozoic Paraná sedimentary basin, the Paranapanema Craton (Mantovani and Brito Neves, 2005).

The first stratigraphic division of the SRG was proposed by Hasui (1976). Subsequently, a two-fold one was proposed, with the basal Boturuna Formation consisting of phyllites with quartzite and metacarbonate intercalations, whereas the upper Piragibu Formation is composed of rhythmic metapsammites succeeded by phyllites that are interbedded with quartzite. This sequence is interpreted to possibly represent turbidity current deposits in a marine environment (Carneiro, 1983; Campos Neto et al., 1983; Dantas, 1990).

Later studies recognized a distinctive volcano-sedimentary sequence in the Serra do Itaberaba region (Coutinho et al., 1982), composed of basic to intermediate tuffs, volcanic and subvolcanic rocks interbedded with chert, banded iron formation (BIF), and detrital sediments. This sequence was later defined as SIG (Juliani et al., 1986), and distinguished from the SRG, based on its higher (amphibolite-facies) metamorphic grade, and the presumed existence of an erosional contact. The latter is delineated by the presence of clasts and volcanic fragments from the SIG in metaconglomerates located at SRG base (Juliani, 1993; Martin, 2000). SIG was dated, by Juliani et al. (2000), by $\mathrm{U}-\mathrm{Pb}$ zircon in metavolcanic rocks at $1395 \pm 10 \mathrm{Ma}$.

A different metavolcano-sedimentary sequence was described in the Pirapora region (Bistrichi, 1982; Bergmann, 1988; Tassinari et al., 2001), which is composed of tholeiitic metabasalts with pillow-lavas (Figueiredo et al., 1982) chemically similar to MORB (Lazzari, 1987; HenriquePinto and Janasi, 2010) and associated with pyroclastics and meta-limestones, showing stromatolite structures (Bergmann and Fairchild, 1985). Bergmann (1988) interpreted the Pirapora Formation as the representation of passive margin volcanic centers surrounded by stromatolites. $\mathrm{U}-\mathrm{Pb}$ zircon $(608 \pm 7 \mathrm{Ma})$ and monazite $(628 \pm 9 \mathrm{Ma})$ dates (Hackspacker et al., 1999; 2000) suggest a Neoproterozoic age for this sequence; however, recent $\mathrm{U}-\mathrm{Pb}$ zircon dating for possible correlative metavolcanic rocks in the Cajamar region indicate an age of $1750 \pm 40 \mathrm{Ma}$ (Oliveira et al., 2008).

The possibility that the SRG base is older than the overlying layers was stated by Van Schmus et al. (1986), based 


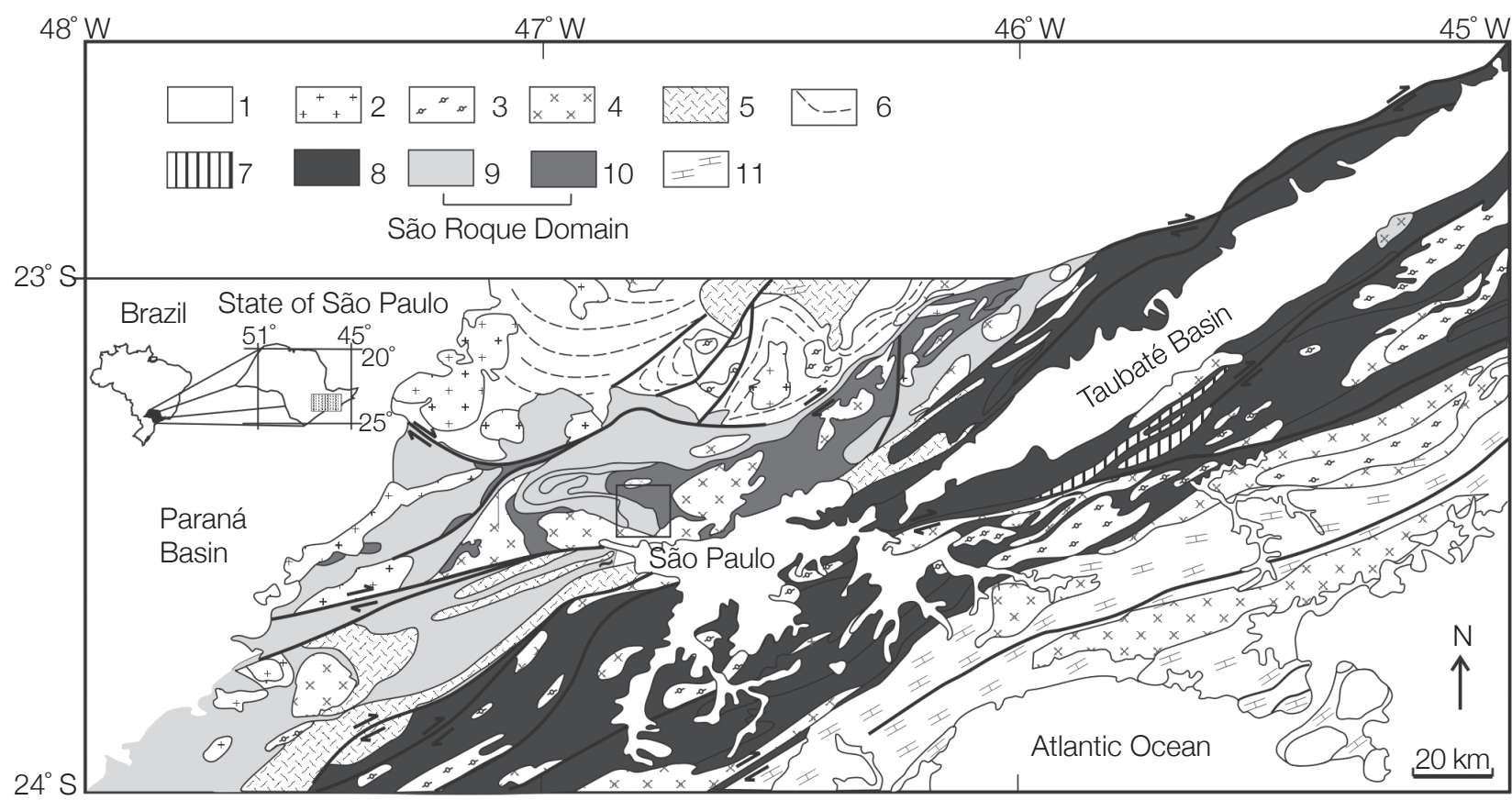

Figure 1. Simplified geotectonic map of the region near the city of São Paulo (modified from Campos Neto, 2000). 1: Phanerozoic cover and intrusive rocks; 2: late and post-tectonic granites; 3: (garnet)-(muscovite)-biotite granites; 4: porphyritic biotite granites; 5: porphyritic (hornblende)-biotite granites; 6: Socorro-Guaxupé domain; 7: Paleoproterozoic gneisses (basement to Embu Domain metasupracrustals); 8: Embu Domain metasupracrustal sequences; 9: São Roque Group and Votuverava Formation; 10: Serra do Itaberaba Group; 11: Costeiro complex. The small box shows the location of Figure 2.

on U-Pb zircon age of $1790 \pm 14 \mathrm{Ma}$ obtained for acid metavolcanic rocks, which are characterized by a withinplate geochemical signature from the Morro do Polvilho region (Henrique-Pinto and Janasi, 2010).

\section{LOCAL GEOLOGY}

A simplified geological map of the study area is presented in Figure 2, where most of the metaconglomerate occurrences from the Boturuna Formation are indicated. The basal unit of the SRG identified by Coutinho (1955) was referred as Morro Doce Formation (Juliani et al., 1999); part of this sequence was also positioned as lower by Cordani et al. (1961) and classified as 'impure metapsammitic' unit (Carneiro, 1983), or 'basal siliciclastic association' (Fernandes da Silva, 2004). However, these studies were conducted in different geographical locations.

The Boturuna Formation crops out predominantly northwest of the city of São Paulo (Figure 2). It is characterized by the predominance of interfingered metarkoses and polymictic metaconglomerates with pebbles and cobbles encased by hard-recrystallized framework. In topographically higher regions (the Jaraguá Peak), occurrences of metasandstones and feldspathic metasandstones ones are present. Small bodies of metavolcanic rocks are intercalated with metarkoses; those are represented by basic metavolcanic rocks (e.g. small lenses of basaltic trachyandesite within the metarkoses), and porphyritic meta-trachydacite (in the Morro do Polvilho region). The meta-trachydacites define a chemical signature typical of within-plate magmatism, with low mg\#, high $\mathrm{Zr}, \mathrm{Y}, \mathrm{Nb}$, and low Sr (Henrique-Pinto and Janasi, 2010).

The Jaraguá amphibolite, with an approximate exposure area of $1.5 \times 2.5 \mathrm{~km}$, occurs in apparent discordance in relation to detrital metasediments (Gomes, 1962). It shares the MORB-like signature of the volcanics from the Pirapora Formation, like low concentrations of incompatible elements such as $\mathrm{Rb}, \mathrm{Nb}$ and $\mathrm{Th}$ (Henrique-Pinto and Janasi, 2010). Small occurrences of impure metalimestones surrounding the main body further suggest a correlation with the Pirapora Formation.

The occurrences of calc-silicate rocks appearing in the north-central portion of the studied area (Cordani et al., 1963 ) belong to SIG, as probably do the scattered occurrences of staurolite-mica schist that appear as windows within the area consisting predominantly of metarkoses from the Boturuna Formation.

The southern portion of the study area (Figure 2) is dominated by Neoproterozoic granitic rocks from Itaqui and Cantareira plutons; the small Fazenda Ithayê Granite, intruding the metarkose unit in the center of the area is 


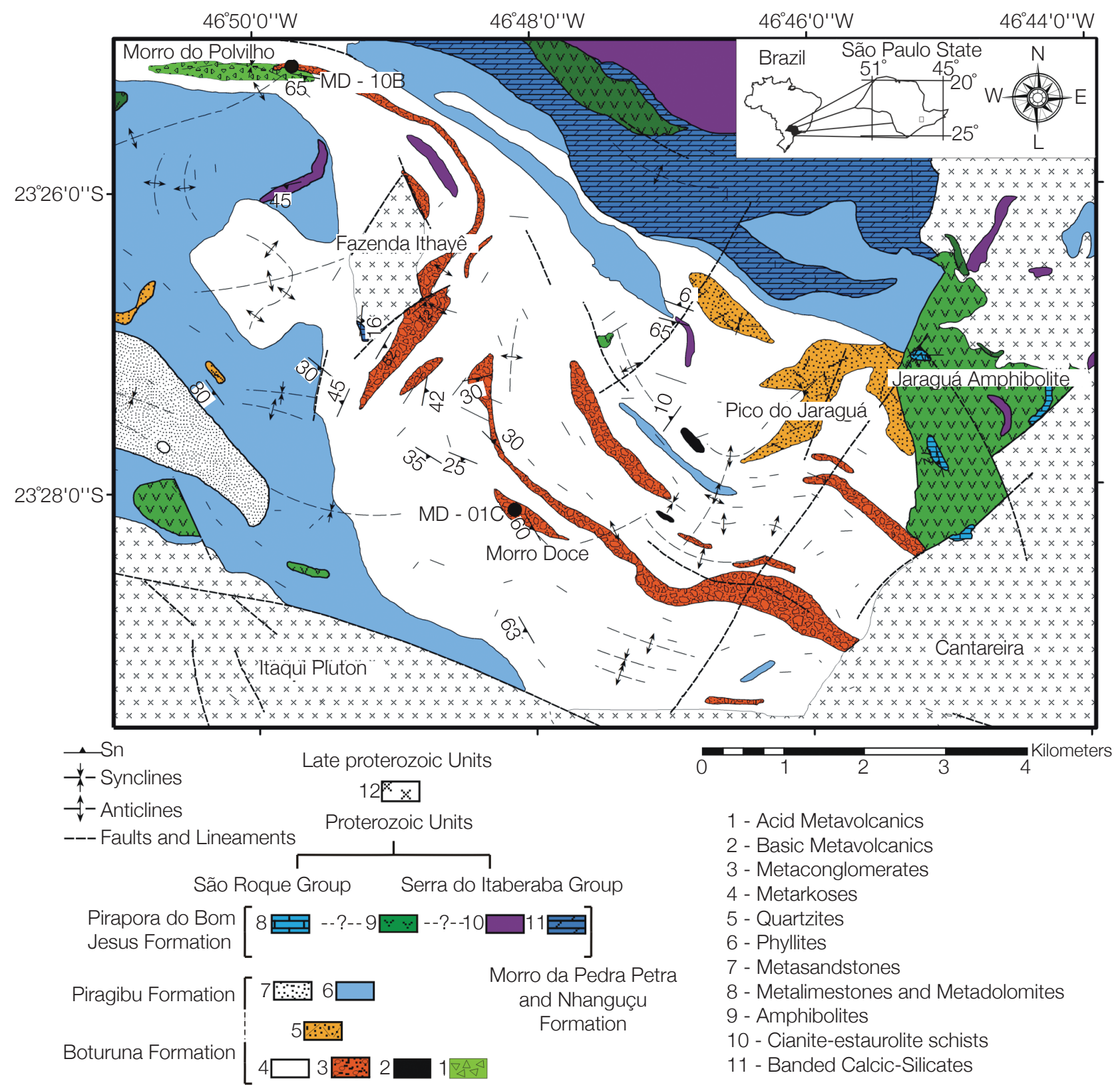

Figure 2. Geological map of São Roque Domain NW of the city of São Paulo (modified from IPT, 1983).

petrographically similar, being dominated by porphyritic biotite ( \pm hornblende) granites. In contrast, the Tico-Tico Granite, part of which appears in the extreme north of the study area, is intrusive in SIG, and consists of two mica leucogranites. Tourmaline-bearing pegmatite and aplite dikes are scattered over most of the area.

Tassinari et al. (1985) obtained a $\mathrm{Rb}-\mathrm{Sr}$ isochron age of $1200 \pm 75 \mathrm{Ma}$ for granitic pebbles from a metaconglomerate of Boturuna Formation. The evolution of the Sr isotopic ratio was used to suggest that the source of pebbles formed at $\sim 2.4 \mathrm{Ga} \mathrm{K}$-Ar ages for groundmass biotite range between 800 to $750 \mathrm{Ma}$, and they were interpreted as representing the last metamorphic event that affected these rocks (Tassinari, 1988).

It is possible that the basal unit (sensu Coutinho, 1955) was deposited in a deep-sea environment (Odman, 1955), which was affected by proximal arkosean terrigenous or even conglomeratic sediments. Petrographic study of granites clasts for SRG metaconglomerates (Henrique-Pinto, 2008; Henrique-Pinto and Janasi, 2010) allowed the identification of four petrographic varieties: porphyritic biotite monzogranite, inequigranular monzogranite, equigranular 
monzogranite, and inequigranular leucogranite. The clasts appear to be broadly comagmatic, as suggested by their definition of a single geochemical evolution trend consistent with normal differentiation in granitic magmas.

The metarkoses show clear chemical affinities with the granitic pebbles from the metaconglomerate; their REE patterns, although similar to the clasts, are characterized by a smaller negative Eu anomaly suggestive of an additional source. This possibly corresponds to a mafic igneous source as indicated by their higher $\mathrm{Cr} / \mathrm{Th}, \mathrm{Ti} / \mathrm{Zr}$, and $\mathrm{Co} / \mathrm{Th}$ ratios (Henrique-Pinto and Janasi, 2010).

\section{ANALYTICAL METHODS}

\section{Zircon separation}

Zircon crystals for $\mathrm{U}-\mathrm{Pb}$ geochronological dating were extracted from two clasts of equigranular muscovite-biotite monzogranite, which represent the most typical variety found in the metaconglomerate at the Morro Doce (MD-01C) and Morro do Polvilho (MD-10B) localities.

The samples were crushed in a steel jaw-crusher and subsequently in a disk mill. The concentrates were obtained in the Mineral Separation Laboratory of Instituto de Geociências, Universidade de São Paulo, in Brazil, by standard procedures involving a vibrating table (Wilfley) and heavy liquids (bromoform and methylene iodide).

Microscopic studies of the heavy mineral concentrates were conducted in transmitted light using a Zeiss Axioplan microscope. The concentrates were then submitted to magnetic separation procedures using a Frantz ${ }^{\mathrm{TM}}$ type isodynamic magnetic separator, initially with $+10^{\circ}$ side and $15^{\circ}$ forward dip. Zircons were concentrated in the nonmagnetic fraction at $1.5 \mathrm{~A}$. The different magnetic fractions of zircons were then split by varying the inclination angle of the separator from $+6^{\circ}$ to lower values, until the last sizeable fraction was obtained. Handpicking involved the selection of the least magnetic crystals with well-preserved prismatic faces, vitreous luster, and least amount of inclusions as possible.

\section{LA-ICPMS U-Pb dating}

Isotopic determinations were conducted at the Department of Earth and Atmospheric Sciences, University of Alberta (Edmonton, Canada), by LA-MC-ICPMS using a $\mathrm{Nu}$ Plasma mass spectrometer equipped with three ion counters and 12 Faraday detectors; this instrument was coupled to a Nd:YAG UP213 nm New Wave laser ablation system. The accuracy and precision of analyses were validated by analysing zircon standards BR266 and 91500. A spot size of $20 \mu \mathrm{m}$ was used for the laser ablation runs given in general the high total $\mathrm{Pb}$ contents of the zircons. This resulted in adequate $\mathrm{U}$ and $\mathrm{Pb}$ ion signal intensities and allowed spots to be located in areas free of fractures and inclusions. Details of the analytical protocol employed here are given in Simonetti et al. (2005).

\section{Sm-Nd analyses}

Sm-Nd isotope analyses were performed at the Centro de Pesquisas Geocronológicas (CPGeo), Instituto de Geociências, Universidade de São Paulo, Brazil, following the procedures described by Sato et al. (1995). The Nd isotopic ratios were obtained using a multicollector Finnigan MAT-262 mass spectrometer, whereas the Sm ones were obtained using a single collector VG-354 mass spectrometer. The average ${ }^{143} \mathrm{Nd} /{ }^{144} \mathrm{Nd}$ values measured for the $\mathrm{La}$ Jolla and BCR-1 Nd standards during the period of this study are $0.511849 \pm 0.000025$ and $0.512662 \pm 0.000027$ (yearly $1 \sigma$ variation), respectively. The maximum measured errors were $0.09 \%$ for the ${ }^{147} \mathrm{Sm} /{ }^{144} \mathrm{Nd}$ ratio and \pm 0.00002 for ${ }^{143} \mathrm{Nd} /{ }^{144} \mathrm{Nd}$ ( $2 \sigma$ precision level). $\varepsilon_{\mathrm{Nd}}$ calculations assume present CHUR ratios of ${ }^{143} \mathrm{Nd} /{ }^{144} \mathrm{Nd}=0.512638$ and ${ }^{147} \mathrm{Sm} /{ }^{144} \mathrm{Nd}=0.1967$. The constant used decay was $6.54 \mathrm{x}$ $10^{-12}$ years $^{-1} . \mathrm{T}_{\mathrm{DM}}$ calculations are made using the method of DePaolo (1988). Details of the analytical protocol employed here are given in Sato et al. (1995).

\section{RESULTS OF LA-ICPMS U-PB DATING}

\section{Sample MD-01C}

Thirty-nine analyses were conducted for sample MD-01C (Table 1). Eight points are essentially concordant (discordance $<3 \%$ ) and yield an average date of $2199 \pm 9$ Ma. This is interpreted as the age of magmatic crystallization for this granitic clast. Two analyses from crystal $6 \mathrm{~b}$, although discordant, are clearly inherited and define discordia with an upper intercept age of $2694 \pm 29 \mathrm{Ma}$ (lower intercept $\sim$ zero), which is indicative of an Archean inheritance (Figure 3). The remaining analyses define a single discordia and yield an upper intercept age of $2209 \pm 14$ $\mathrm{Ma}$, which is within uncertainty to the average age (2199 $\pm 9 \mathrm{Ma})$, defined by the concordant crystals. The lower intercept age at $527 \pm 72 \mathrm{Ma}$ reflects the overprint associated with the Neoproterozoic thermal event (Figure 3).

\section{Sample MD-10B}

Thirty-two analyses were conducted for sample MD-10B (Morro do Polvilho region), of which six were excluded from regression because of for their complex zoning and multiple age domains (Table 2). The remaining 26 points 
г ล்

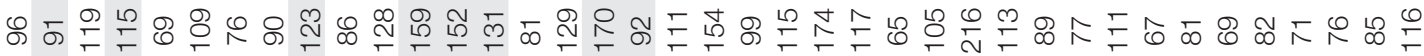

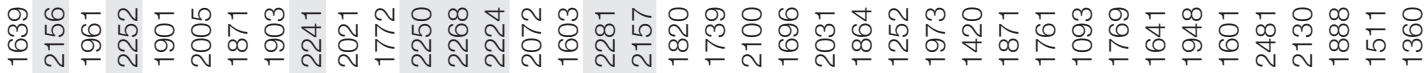

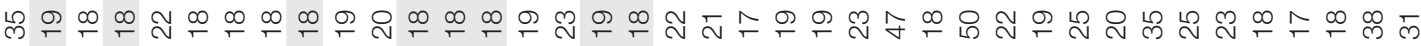

士

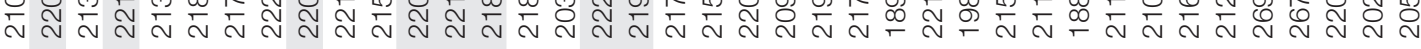

广 000000000000000000000000000000000000000

ᄋ

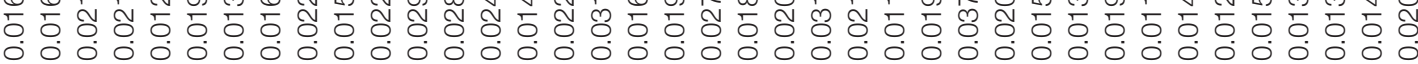

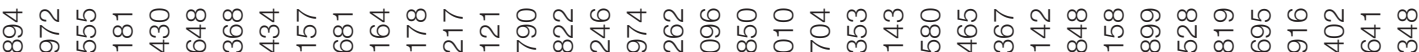

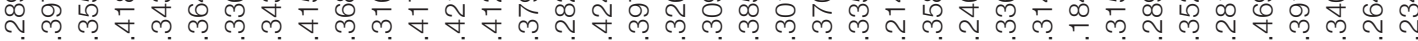

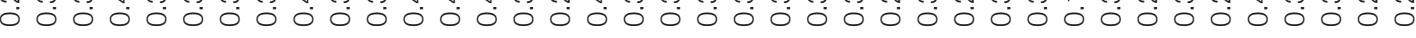

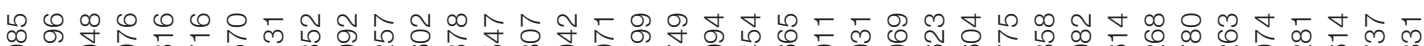
穴

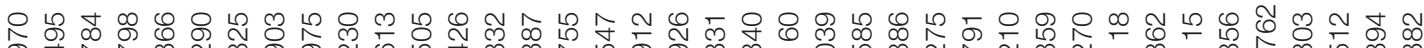

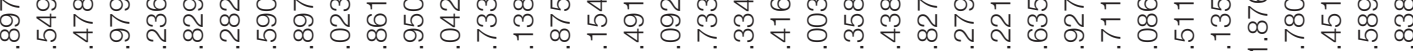
ச゙

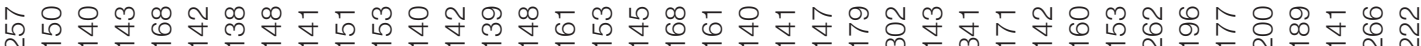

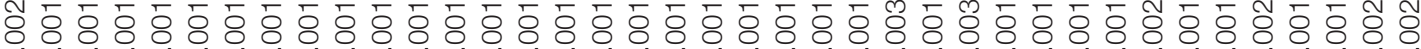

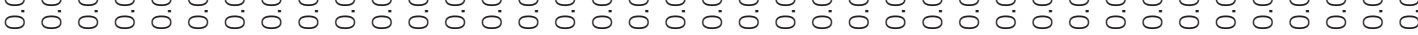

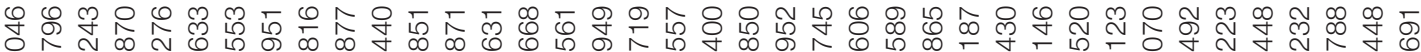

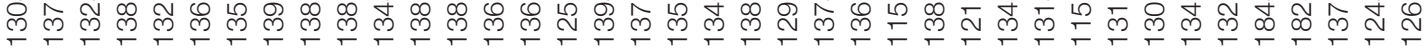
000000000000000000000000000000000000000

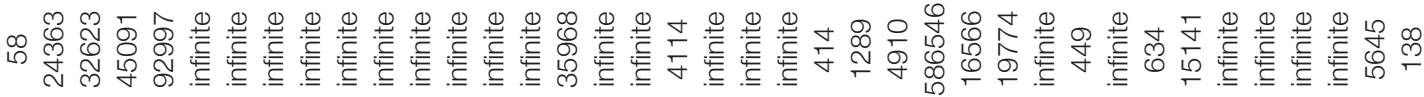

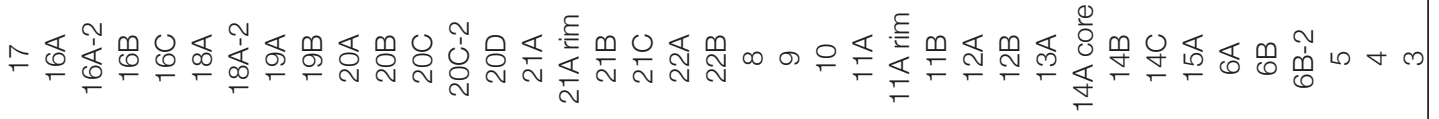



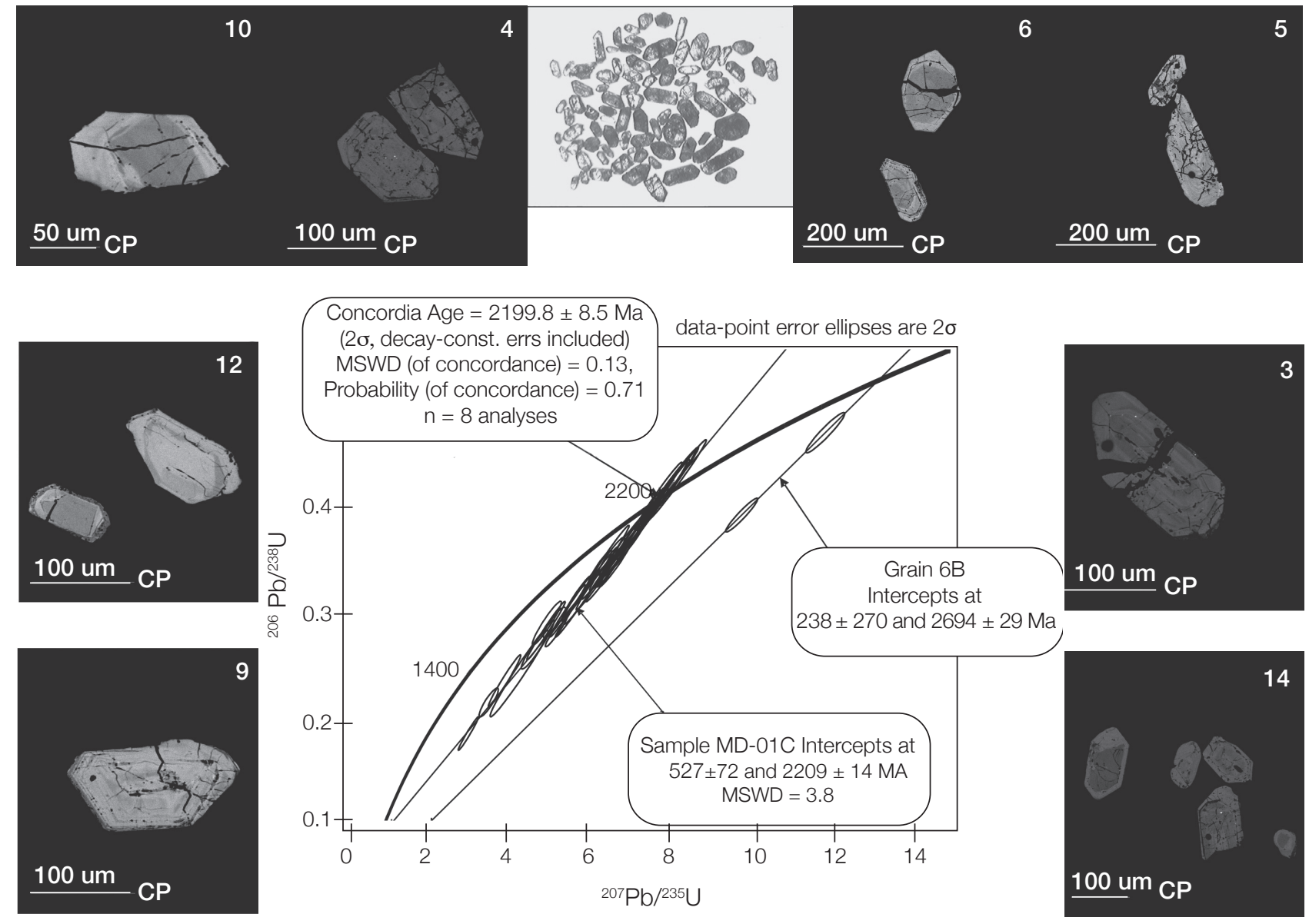

Figure 3. Concordia plot for LA-MC-ICPMS U-Pb zircon dating of sample MD-01C, a biotite monzogranite clast from the Morro Doce region. Backscattering images obtained by scanning electron microscopy with numbers linked to Table 1.

indicate variable degrees of discordance, between 4 and $22 \%$, and define a discordia with an upper intercept age at $2247 \pm 13 \mathrm{Ma}$; which is interpreted as the magmatic crystallization age for this granite clast. The lower intercept age at $637 \pm 84 \mathrm{Ma}$ once again reflects the overprint associated with the Neoproterozoic thermal event (Figure 4).

\section{Sm-Nd Data}

Sm-Nd isotope data were obtained from six representative samples of the main clast varieties of the Morro Doce metaconglomerate, all from outcrop MD-01. Results are listed in Table 3 and illustrated in Figure 5. Given a 2.2 Ga magmatic crystallization age, $\varepsilon_{\mathrm{Nd}(t)}$ values are all negative and appear to cluster between values from -3.1 to -4.3; an exception is the inequigranular granite sample MD-01D that is characterized by a more negative value of -6.7. The metarkose framework is slightly less negative $\left(\varepsilon_{\mathrm{Nd}(t)}=-2.3\right)$, suggesting contribution from a distinct source, perhaps of mafic character, a feature also suggested by whole-rock chemistry (Henrique-Pinto and Janasi, 2010). Interestingly, the amphibolite clast does not seem to equate to this same source since its $\varepsilon_{\mathrm{Nd}(t)}(-3.6)$ at $\mathrm{t}=2.2$ $\mathrm{Ga}$ is within the same range for most of the granite clasts.

The Sm-Nd $\mathrm{T}_{\mathrm{DM}}$ ages of the granitic clasts and the metarkose framework cluster at 2.6 to $2.7 \mathrm{Ga}$ (Figure 5), combined with the inherited age (2694 $\pm 29 \mathrm{Ma})$ reported in sample MD-01C, reinforces the idea that these granites are products of remelting a $\sim 2.7 \mathrm{Ga}$ crustal component. The older TDM age (3.2 Ga, Table 3 ) defined by the inequigranular leucogranite MD-01D can be a reflection of its higher ${ }^{147} \mathrm{Sm} /{ }^{144} \mathrm{Nd}$ ratio (0.135), and may result from LREE fractionation during magma evolution (HenriquePinto and Janasi, 2010). Hence, this older TDM age most probably does not have any geological significance. The ${ }^{147} \mathrm{Sm} /{ }^{144} \mathrm{Nd}$ ratio of the metabasic clast $(0.126)$ is typical for this rock type, its $\mathrm{T}_{\mathrm{DM}}$ age $(2.8 \mathrm{Ga})$ is slightly older than those of the typical granite clasts.

\section{DISCUSSION}

The metaconglomerates from the Boturuna Formation (basal unit of SRG) are part of the detrital sedimentary 


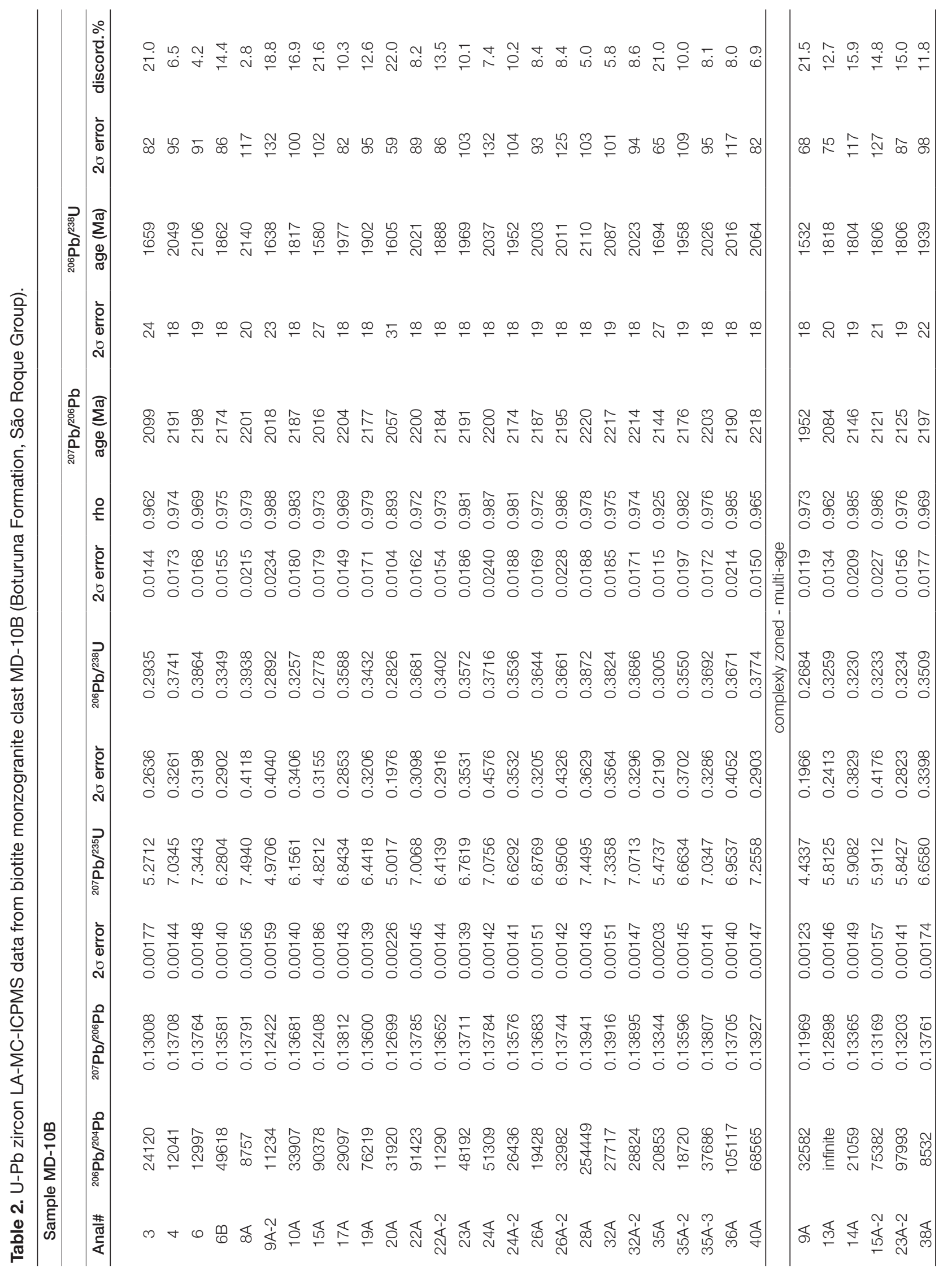



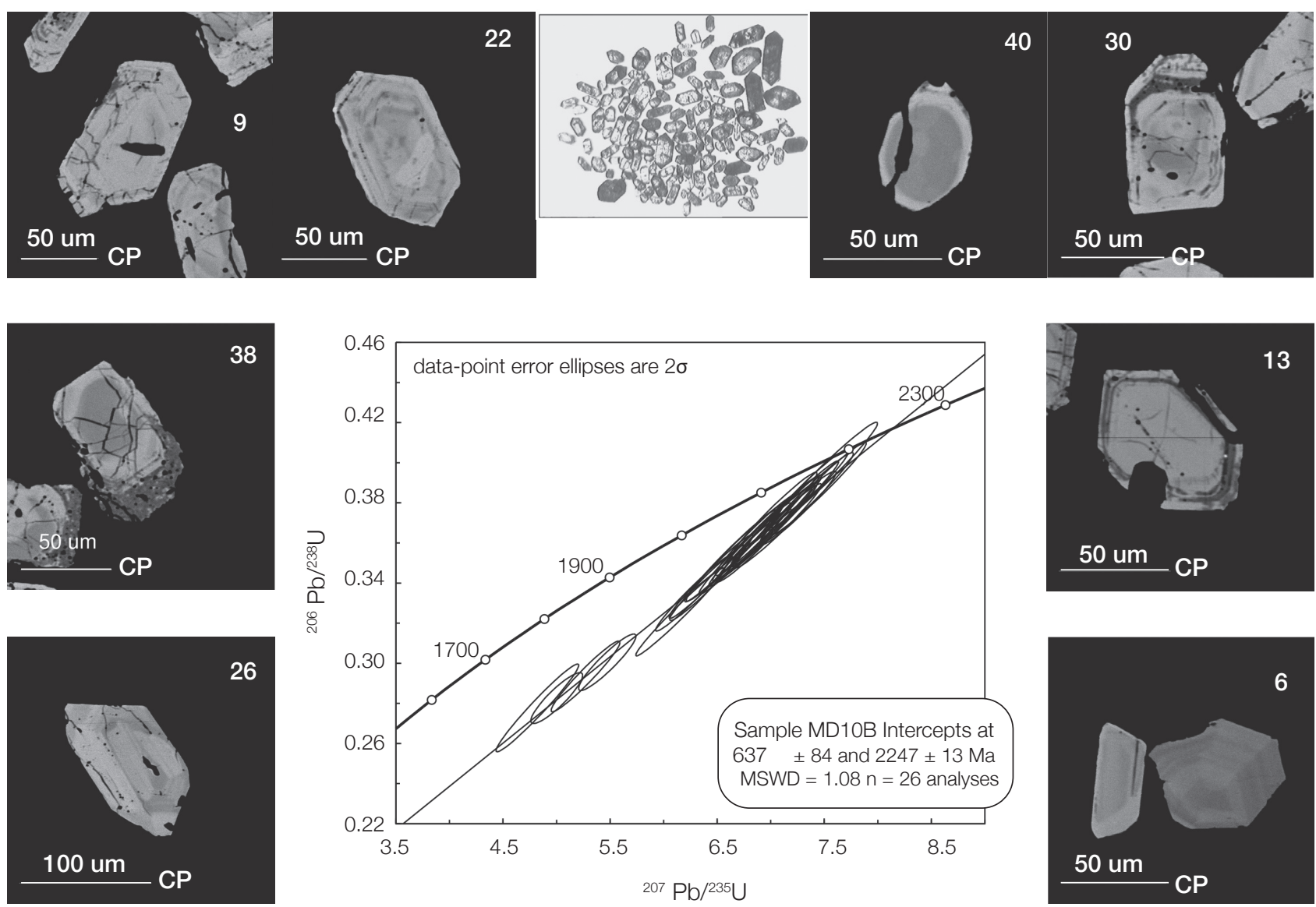

Figure 4. Concordia plot for LA-MC-ICPMS U-Pb zircon dating of sample MD-10B, a biotite monzogranite clast from the Morro do Polvilho region. Backscattering images obtained by scanning electron microscopy with numbers linked to Table 2.

Table 3. Sm-Nd isotope data for clasts and framework of metaconglomerate MD-01 (Boturuna Formation, São Roque Group).

\begin{tabular}{lcccccccccc}
\hline Samples & Clasts & $\begin{array}{c}\mathrm{Sm} \\
\mathbf{p p m})\end{array}$ & $\begin{array}{c}\mathbf{N d} \\
(\mathbf{p p m})\end{array}$ & $\begin{array}{c}{ }^{147} \mathrm{Sm} / \\
{ }^{144} \mathrm{Nd}\end{array}$ & Error & ${ }^{143} \mathrm{Nd} /$ & Error & $\begin{array}{c}\mathrm{T}_{\mathrm{DM}} \\
(\mathrm{Ga})\end{array}$ & $\boldsymbol{\varepsilon}_{(0)}$ & $\boldsymbol{\varepsilon}_{(\mathbf{t})}$ \\
\hline MD-01B & Metarkose framework & 5.856 & 34.745 & 0.1019 & 0.0006 & 0.511160 & 0.000011 & 2.6 & -28.84 & -2.25 \\
MD-01C & Equigranular granite & 5.752 & 42.047 & 0.027 & 0.0005 & 0.510779 & 0.000008 & 2.7 & -36.27 & -4.30 \\
MD-01D & Inequigranular leucogranite & 1.900 & 8.514 & 0.1349 & 0.0008 & 0.511409 & 0.000012 & 3.2 & -23.98 & -6.66 \\
MD-01E & Inequigranular granite & 6.005 & 39.859 & 0.0911 & 0.0005 & 0.510961 & 0.000012 & 2.6 & -32.71 & -3.09 \\
MD-01M & Metabasic rock & 1.261 & 6.063 & 0.1257 & 0.0007 & 0.511431 & 0.000014 & 2.8 & -23.55 & -3.64 \\
MD-01N & Porphyritic granite & 7.629 & 46.601 & 0.0990 & 0.0006 & 0.511068 & 0.000010 & 2.6 & -30.62 & -3.22 \\
\hline
\end{tabular}

$\mathrm{t}=2.2 \mathrm{Ga}$, the crystallization age of the granite clasts; $\mathrm{T}_{\mathrm{DM}}$ according to DePaolo (1988).

sequences indicating proximal sources, as identified by the presence of pebbles and boulders supported by an arkosean framework. Thus, these rocks have an excellent potential for characterizing the main source for the SRG.

$\mathrm{U}-\mathrm{Pb}$ dating by LA-MC-ICP-MS of zircons extracted from predominantly equigranular monzogranites clasts within the Morro Doce and Morro do Polvilho regions indicate Paleoproterozoic ages for magmatic crystallization (2199 \pm 9 Ma and $2247 \pm 13 \mathrm{Ma}$, respectively). Even taking into account the $\sim 10$ Ma uncertainties associated with each date, the ca. 50
Ma difference between the two ages is suggestive that these clasts, although very similar in petrography and chemistry, are not strictly comagmatic, i.e., do not derive from exactly the same source.

The polycyclic history of the zircons is reinforced by the presence of inherited grains found in the clast MD-01B in the Morro Doce occurrence (2694 $\pm 29 \mathrm{Ma})$. Furthermore, both dated clasts were also affected by a neoproterozoic event, as indicated by lower intercept dates in the 530 to 640 Ma range. Although imprecise, the latter dates can be attributed to the 


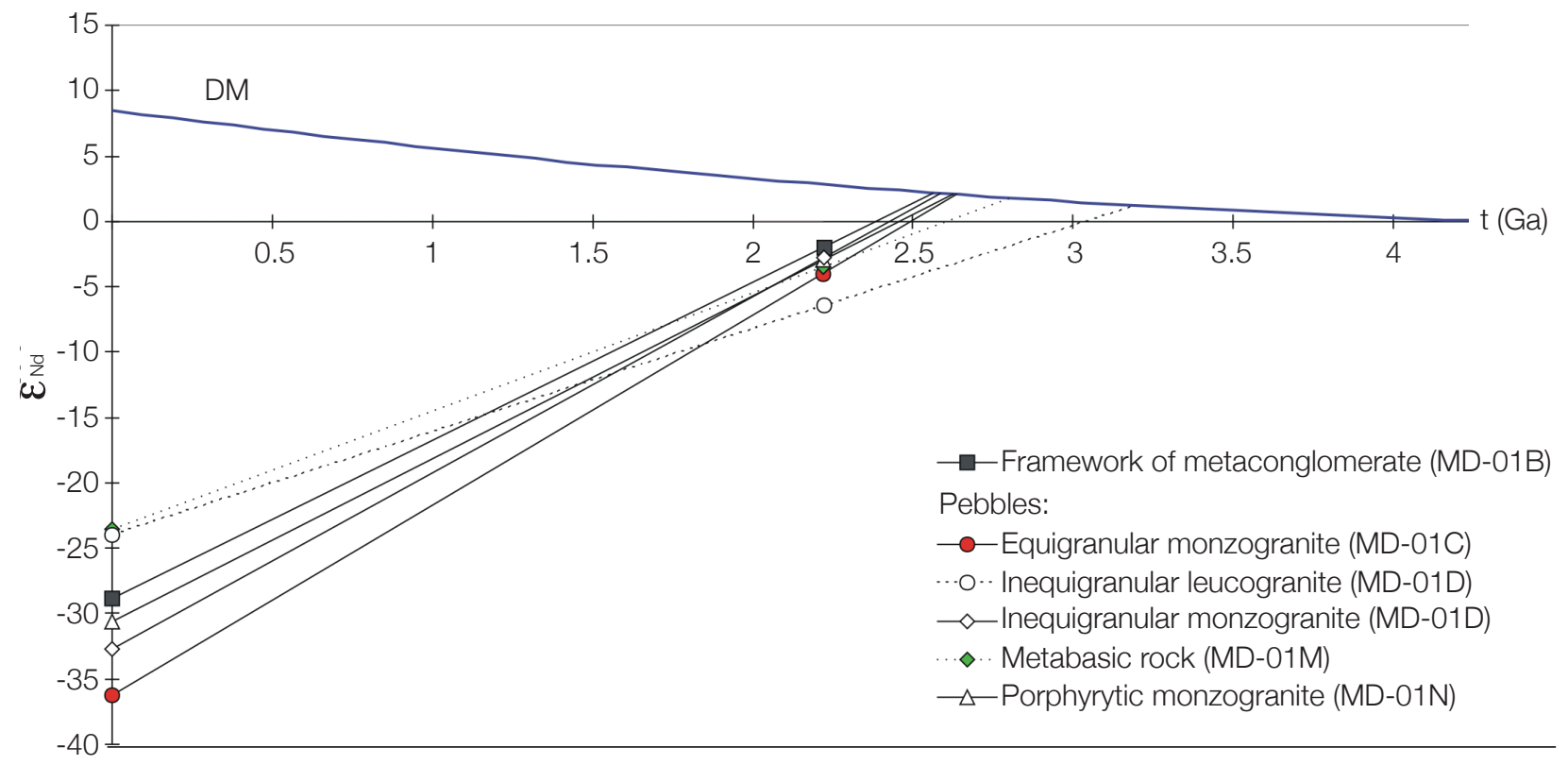

DM: evolution line of the depleted mantle (De Paolo, 1988).

Figure 5. $\varepsilon_{\mathrm{Nd}}$ versus $\mathrm{t}(\mathrm{Ga})$ diagram of main granite clasts of Boturuna Formation.

important thermal event of metamorphism and intrusion of large amounts of granitic plutons that affected the Apiaí-São Roque Domain and the Socorro-Guaxupé Nappe, which together correspond to the reworked border of the Paranapanema Craton (Campos Neto, 2000).

The ages of the granite clasts are not documented in basement granitic rocks that occur at the southwestern margin of São Francisco craton, which are typically slightly younger and range between 2020 and $2140 \mathrm{Ma}$ (Campos Neto et al., 2004). Similar ages are found in the basement of Espinhaço Supergroup in eastern São Francisco Craton (Mineiro Belt; Teixeira et al., 2008). However, correlation with some parts of the São Francisco Craton seems improbable, since the ApiaíSão Roque Domain is thought to belong to a different paleocontinent (Paranapanema). It seems more probable, therefore, that equivalents are present in the basement of the Açungui Supergroup as exposed in the Tigre, Setuva and Betari nuclei, where orthogneisses of similar age are described (Kaulfuss, 2001; Cury et al., 2002; Siga Jr. et al., 2007). Remarkably, the latter are intruded by younger $(\sim 1.75 \mathrm{Ga})$ syenogranitic orthogneisses, which are considered to represent an extensional tectonic event (Kaulfuss, 2001; Siga Jr. et al., 2011) that is possibly equivalent to the one that generated the bimodal metavolcanic sequence of within-plate geochemical signature described in the SRG (Henrique-Pinto and Janasi, 2010).

$\mathrm{Sm}-\mathrm{Nd}$ isotope data from the main clast varieties from the Morro Doce metaconglomerates yield $\mathrm{T}_{\mathrm{DM}}$ ages of 2.6 to $2.7 \mathrm{Ga}$, indicating that these granites are the recycling products of an Archean crust; an interpretation that is corroborated with the presence of an inherited zircon dated at $\sim 2.7 \mathrm{Ga}$. The metaconglomerate arkosean framework yields slightly lower $\varepsilon_{\mathrm{Nd}(\mathrm{t})}$ values compared to the clasts, therefore younger and/or more mafic source may contribute to the Boturuna Formation. This is in agreement with the geochemical signature of the associated metarkoses since a mafic igneous input was identified based on the whole-rock geochemistry (Henrique-Pinto and Janasi, 2010).

\section{REFERENCES}

BERGMANN, M. Caracterização Estratigráfica e Estrutural da Seqüencia Vulcano-Sedimentar do Grupo São Roque na Região de Pirapora do Bom Jesus - Estado de São Paulo. 1988. Dissertação de Mestrado - Instituto de Geociências, Universidade de São Paulo, São Paulo.

BERGMANN, M.; FAIRCHILD, T.R. Estromatólitos do Grupo São Roque, Proterozóico Superior, Região de Pirapora de Bom Jesus, Estado de São Paulo. Anais da Academia Brasileira de Ciências, v. 57, n. 1, p. 116-117, 1985.

BISTRICHI, C.A. Geologia do Sinclinório de Pirapora, SP. 1982. Dissertação de Mestrado - Instituto de Geociências, Universidade de São Paulo, São Paulo.

CAMPOS NETO, M.C.; BASEI, M.A.S; ARTUR, A.C.; SILVA, M.E.; MACHADO, R.; DIAS NETO, C.M.; FRAGOSO CESAR, A.R.; SOUZA, A.P. Geologia das Folhas Piracaia e Igaratá. IPT - Pró-Minério, $1^{\text {a }}$ Jornada Sobre a Carta Geológica do Estado de São Paulo em 1: 50,000. 1983, p. 55-76. 
CAMPOS NETO, M.C. Orogenic Systems From Southwestern Gondwana: an Approach to Brasiliano-Pan African Cycle and Orogênic Collage in Southeastern Brazil. In: XXXI INTERNATIONAL GEOLOGICAL CONGRESS, 2000. Extended Abstracts, Rio de Janeiro, Brazil, 2000, p. 335-365.

CAMPOS NETO, M.C.; BASEI, M.A.S.; VLACH, S.R.F.; CABY, R.; SZABO, G.A.J.; VASCONCELOS, P. Migração de Orógenos e Superposição de Orogêneses: Um Esboço da Colagem Brasiliana no Sul do Cráton do São Francisco, SE-Brasil. Geologia USP: Série Científica, São Paulo, v. 4, p. 13-40, 2004.

CARNEIRO, C.D.R. Análise Estrutural do Grupo São Roque na Faixa entre o Pico do Jaraguá e a Serra dos Cristais, SP. 1983. Tese (Doutorado) - Instituto de Geociências, Universidade de São Paulo, São Paulo.

CORDANI, U.G.; CAMPOS, A.C.R.; DAVINO, A.; BJÖRNBER, A.J.S. Geologia da Região do Jaraguá. Boletim da Sociedade Brasileira de Geologia, São Paulo, v. 10, n. 20, p. 73-91, 1961.

CORDANI, U.G.; GOMES, C.B.; GIRARDI, V.A.V. Rochas Cálcio-Silicatadas da Região de Perus, SP. Anais da Academia Brasileira de Ciências, v. 35, n. 3, p. 361-372, 1963.

COUTINHO, J.M.V. Metaconglomerado e rochas associadas no Município de São Paulo. Boletim Faculdade de Filosofia Ciências e Letras, Universidade de São Paulo, São Paulo, v. 186, Mineralogia 13, p. 5-56, 1955.

COUTINHO, J.M.V.; RODRIGUES, E.P.; SUEMITSU, A.; JULIANI. C.; BELJAVSKIS, P.; PAULO, T.Y.P. Geologia e Petrologia da Seqüência Vulcano-Sedimentar do Grupo São Roque na Serra de Itaberaba - SP. In: XXXII CONGRESSO BRASILEIRO DE GEOLOGIA, Salvador, Anais..., v. 2, 1982, p. 624-640.

CURY, L.F.; KAULFUSS, G.A.; SIGA JR., O.; BASEI, M.A.S.; HARARA, O.M.; SATO, K. Idades U-Pb (Zircões) de 1.75 Ga em Granitóides Alcalinos Deformados dos Núcleos Betara e Tigre: Evidências de Regimes Extensionais do Estateriano na Faixa Apiaí. Geologia USP, Série Científica, v. 2, p. 95-108, 2002.

DANTAS, A.S.L. Geologia da Faixa São Roque e Intrusivas Associadas na Região entre São Paulo e Mairiporã, Norte de São Paulo. 1990. Dissertação de Mestrado - Instituto de Geociências, Universidade de São Paulo, São Paulo.

DEPAOLO, D.J. Neodymium Isotope Geochemistry. An Introduction. Springer, Berlin, 1988. 187 p.
DERBY, O.A. Relatório acerca dos estudos geológicos praticados nos Valles do rio das Velhas e alto S. Francisco. Apresentado ao Conselheiro Manoel de Araújo, 29 de março, 1882. Typographia Nacional, Rio de Janeiro.

FERNANDES DA SILVA, P.C. Litofácies e Prováveis Ambientes de Sedimentação do Grupo São Roque na Região de Votorantim e Salto de Pirapora, SP. Revista do Instituto Geológico, São Paulo, v. 25, n. 1/2, p. 29-48, 2004.

FIGUEIREDO, M.C.H.; BERGMANN, M.; PENALVA, F.; TASSINARI, C.C.G. Ocorrência de pillow-lavas no Grupo São Roque, Estado de São Paulo. Revista Ciências da Terra, v. 2, p. 6-8, 1982.

GOMES, C.B. Contribuição ao Conhecimento dos Anfibolitos da Região do Jaraguá, SP. Boletim Sociedade Brasileira de Geologia, São Paulo, v. 11, n. 1, p. 57-73, 1962.

HACKSPACHER, P.C.; DANTAS, E.L.; GODOY, A.M.; OLIVEIRA, M.A.F.; FETTER, A.; VAN SCHMUS, W.R. Considerations About the Evolution of the Ribeira Belt in the São Paulo State - Brazil, From U/Pb Geochronology in Metavolcanic Rocks of the São Roque Group. In: II SOUTH AMERICAN SYMPOSIUM ON ISOTOPE GEOLOGY. Cordoba, Argentina, Actas, 1999, p. 310-313.

HACKSPACHER, P.C.; DANTAS, E.L.; SPOLADORE, A.; FETTER, A.H.; OLIVEIRA, M.A.F. Evidence for Neoproterozoic back-arc basin development in the Central Ribeira Belt, southeastern Brazil: new geochronological and geochemical constraints from the São Roque-Açungui Groups. Revista Brasileira de Geociências, v. 30, p. 110-114, 2000.

HASUI, Y. Considerações Sobre a Estratigrafia do PréCambriano na Região de São Paulo. Boletim Instituto de Geociências, Universidade de São Paulo, São Paulo, v. 7, p. 107-112, 1976.

HENRIQUE-PINTO, R. Metaconglomerados e Rochas Associadas do Grupo São Roque a Noroeste da Cidade de São Paulo: Proveniência e Implicações para a Idade da Sedimentação. 2008. Dissertação de Mestrado - Instituto de Geociências, Universidade de São Paulo, São Paulo.

HENRIQUE-PINTO, R.; JANASI, V.A. metaconglomerados e Rochas Associadas do Grupo São Roque a Norte da Cidade de São Paulo, Brasil. Revista Brasileira de Geociências, v. 40, n. 3, p. 409-425, 2010.

INSTITUTO DE PESQUISAS TECNOLÓGICAS - IPT. Carta Geológica do Estado de São Paulo em Escala 1:50.000. Secretaria da Indústria, Comércio, Ciência e Tecnologia, Pró-Minério, 1983. 
JULIANI, C.; BELJAVSKIS, P.; SCHORSCHER, H.D. Petrogênese do Vulcanismo e Aspectos Metalogenéticos Associados: Grupo Serra do Itaberaba na Região do São Roque - SP. In: XXXIV CONGRESSO BRASILEIRO DE GEOLOGIA, Goiânia. Anais 2, 1986. p. 730-745.

JULIANI, C. Geologia, Petrogênese e Aspectos Metalogenéticos dos Grupos Serra do Itaberaba e São Roque na Região das Serras do Itaberaba e Pedra Branca, NE da Cidade de São Paulo, SP. 1993.2 v. Tese (Doutorado) - Instituto de Geociências, Universidade de São Paulo, São Paulo.

JULIANI, C.; MARTIN, M.A.B.; CLARIMUNDO, S.J.; MCREATH, I.; PERTERSEN Jr. K.J. Geologia dos Grupos Serra do Itaberaba e São Roque entre o Pico do Jaraguá e Araçarigüama, São Paulo. In: SIMPÓSIO DE GEOLOGIA DO SUDESTE, SBG/NSP-NRJ/ES Águas de São Pedro, Boletim de Resumos, 1999. v. 6, p. 26.

JULIANI, C.; HACKSPAKER, P.; DANTAS, E.L.; FETTER, A.H. The Mesoproterozoic volcano-sedimentary Serra do Itaberaba Group of the central Ribeira Belt, São Paulo, Brazil: implications for the age of the overlying São Roque Group. Revista Brasileira de Geociências, v. 30, p. 82-86, 2000.

KAULFUSS, G.A. Geocronologia dos Núcleos de Embasamento Setuva, Betara e Tigre, Norte de CuritibaParaná. 2001. Dissertação de Mestrado - Instituto de Geociências, Universidade de São Paulo, São Paulo.

LAZZARI, M.L. o Metabasito de Pirapora do Bom Jesus. 1987. Dissertação de Mestrado - Instituto de Geociências, Universidade de São Paulo, São Paulo.

MANTOVANI, M.S.M.; BRITO NEVES, B.B. The Paranapanema Lithospheric Block: Its Importance for Proterozoic (Rodinia, Gondwana) Supercontinent Theories. Gondwana Research, v. 8, p. 303-315, 2005.

MARTIN, M.A.B. Geologia e Petrografia e Metamorfismo dos Grupos Serra do Itaberaba e São Roque a Noroeste da Cidade de São Paulo (SP). 2000. Dissertação de Mestrado - Instituto de Geociências, Universidade de São Paulo, São Paulo.

ODMAN, O.H. A Pre-Cambrian Conglomerate With Pebbles of Deep-Seated Rocks Near São Paulo, Brazil. Engenharia, Mineração e Metalurgia, v. 21, n. 121, p. 32, 1955.

OLIVEIRA, M.A.F.; MELO, R.P.; NARDY, A.J.R.; ARAB, P.B.; TRINDADE, I. New U/Pb Palaeoproterozoic Zircon Age For The Cajamar Metabasite, São Roque Group, Central Ribeira Belt, Southeastern Brazil. In: VI SOUTH AMERICAM SYMPOSIUM ON ISOTOPE
GEOLOGY. San Carlos de Bariloche, Argentina, 2008. p. 1-4.

SATO, K.; TASSINARI， C.C.G.; KAWASHITA， K.; PETRONILHO, L. Método geocronológico Sm- Nd no IGUSP e suas aplicações. Anais da Academia Brasileira de Ciências, v. 67, n. 3, p. 315-336, 1995.

SIGA Jr O.; BASEI, M.A.S.; PASSARELLI, C.R.; HARARA, O.M.; SATO, K.; CURY, L.F.; PRAZERES FILHO, H.J. Geocronologia das Rochas Gnáissico-Migmatíticas e Sienograníticas do Núcleo Setuva(PR): implicações tectônicas. Revista Brasileira de Geociências, v. 37, n. 1, p. 114-128, 2007.

SIGA Jr O.; CURY, L.F.; McREATH, I.; RIBEIRO, L.M.A.L.; SATO, K.; BASEI, M.A.S.; PASSARELLI, C.R. Geology and geochronology of the Betara region in south-southeastern Brazil: Evidence for possible Statherian (1.80-1.75 Ga) and Calymmian (1.50-1.45 Ga) extension events. Gondwana Research, v. 19, n. 1, p. 260-274, 2011.

SIMONETTI, A.; HEAMAN, L.M.; HARTLAUB, R.P.; CREASER, R.A.; MACHATTIE, T.G. U-Pb Zircon Dating by Laser Ablation-MC-ICP-MS Using a New Multiple Ion Counting Faraday Collector Array. Journal of Analytical Atomic Spectrometry, v. 20, p. 677-686, 2005.

TASSINARI, C.C.G. As Idades das Rochas e dos Eventos Metamórficos da Porção Sudeste do Estado de São Paulo e sua Evolução Crustal. 1988. Tese (Doutorado) - Instituto de Geociências, Universidade de São Paulo, São Paulo.

TASSINARI, C.C.G.; KAWASHITA, K.; KIKUCHI, R.K.P. Estudo Geocronológico nos Metaconglomerados do Grupo São Roque, Estado de São Paulo. In: X SIMPÓSIO REGIONAL DE GEOLOGIA, São Paulo, Boletim de Resumos, 1985, v. 1, p. 201-208.

TASSINARI, C.C.G.; MUNHÁ, J.M.U.; CORREIA, C.T. Neoproterozoic Oceans in the Ribeira Belt (southeastern Brazil): The Pirapora do Bom Jesus Ophiolitic Complex. Episodes, v. 24, n. 4, p. 245-251, 2001.

TEIXEIRA, W.; ÁVILA, A.C.; NUNES, L.C. Nd-Sr Isotopic Geochemistry and U-Pb Geocronology of the Fé Granitic Gneiss and Lajedo Granodiorite: Implications for Paleoproterozoic Evolution of the Mineiro Belt, Southern São Francisco Craton, Brazil. Geologia USP: Série Cientifica, São Paulo, v. 8, n. 1, p. 53-74, 2008.

VAN SCHMUS, W.R.; TASSINARI, C.C.G.; CORDANI, U.G. Estudo Geocronológico da Parte Inferior do Grupo São Roque. In: XXXIV CONGRESSO BRASILEIRO DE GEOLOGIA, 34, Goiânia, Anais, 3 v, 1986, p. 1399-1406. 